\title{
Monitoring of Antioxidant and Antidiabetic Activity of Fractions from Ethyl Acetate Extract in Garcinia latissima Miq. Stem Bark
}

\author{
Qurrota A'yun Thoyyibah, and Taslim Ersam \\ Department of Chemistry, Institut Teknologi Sepuluh Nopember, Surabaya \\ e-mail:paktichem@gmail.com.
}

\begin{abstract}
The genus Garcinia (Fam. Cluciaciae) is known as a source of phenolic compounds which are reported to have biological activities: antioxidants, antidiabetic, and anticancer etc. In this study, the monitoring was carried out for the antioxidant and antidiabetic activity of a number of fractions from the ethyl acetate extract of stem bark G. latissima Miq. (endemic plants, the Maluku Islands, Indonesia). The extraction process uses the maceration method with ethyl acetate solvent produced $240 \mathrm{~g}$ extract from $2 \mathrm{~kg}$ from dry bark of G. latissima Miq. Furthermore, the ethyl acetate extract was carried out by fractionation by Vacuum Liquid Chromatography (VLC) over the silica gel column and eluted using a mixture of n-hexane and ethyl acetate, with increasing polarity, and were obtained nine fractions (A-I). The Ethyl acetate extract and the all fractions were tested for antioxidant activities using radical DPPH $(2,2-$ diphenyl-1-picrylhydrazyl) and antidiabetic activity using baker's yeast and rat intestinal acetone powder. The inhibititon value ( $\left(\mathrm{IC}_{50}\right)$ of fraction $\mathrm{H}$ was $0.03 \mu \mathrm{g} / \mathrm{mL}$ and fraction I was 0.06 $\mu \mathrm{g} / \mathrm{mL}$. Antidiabetic inhibititon value $\left(\mathrm{IC}_{50}\right)$ using yeast of fraction $H$ was $102.33 \mu \mathrm{g} / \mathrm{mL}$ and fraction I was $29.51 \mu \mathrm{g} / \mathrm{mL}$, on the other hand antidiabetic inhibititon value $\left(\mathrm{IC}_{50}\right)$ using rat intestinal of fraction $\mathrm{H}$ was $43.65 \mu \mathrm{g} / \mathrm{mL}$ and fraction I was 75.86 $\mu \mathrm{g} / \mathrm{mL}$. Based on monitoring data, it shown that the polar fraction $H$ and $I$ has the best inhibition activity than the other positive fractions, so that the active compound in fraction $\mathrm{H}$ and I need to be produced.
\end{abstract}

Keywords-Baker's Yeast, DPPH, Garcinia latissima, Rat Intestinal.

\section{INTRODUCTION}

$I_{b}^{N}$ NDONESIA is a tropical country with the second most biodiversity in the world after Brazil. As many as $15.3 \%$ of the world's biodiversity was found in Indonesia and some of them are endemic. Biodiversity is a national asset that must be considered for its existence, because it is an attraction of Indonesia and beneficial for human welfare. It have been used by the tribe as building materials, fuel, economic resources, food and medicine [1].

Biodiversity in Indonesia, especially flora is an abundant natural chemical industry that can be produced and utilized throughout the year. One group of higher plants with the highest number of species in all tropical countries is the Clusiaceae family. A total of 27 genus out of a total of about 100 genus (the Clusiaceae family) found in Indonesia include the genus Garcinia [2].
The genus Garcinia is known as tropical plant grow along the equator, such Latin America, Central Africa and Southeast Asia. It has been known as a source of phenolic compounds and previous studies reported the isolated compounds have biological activity as antioxidant, anticancer, antidiabetic, etc [3]-[6]. In Indonesia, there are 64 species Garcinia widespread in major island (Sumatera, Kalimantan, Jawa, Sulawesi, Maluku, and Papua) [7]. A number of the Garcinia species have been used by the tribe as traditional medicine such as G. celebica used as a medicine for jaundice in Maluku, G. dulcis used to treat mumps desease, tonsilitis, and skin desease in West Java, and G. mangostana used as a drug for ulcer, cough, inflammation, and diarrhea in Kalimantan [8]. One of the species of the genus Garcinia which is an Indonesian endemic plant is Garcinia latissima Miq. which grows on the Maluku islands and Papua (and successfully cultivated in the Bogor Botanical Garden). Maluku's tribes use this plant as an antidote and Papua's tribes use it as itch medicine. The research related to compound isolated from G. latissima stem bark have been conducted by Ito, et al. (1997) and Purbowati and Ersam (2019) [9][10].The latest study reported by Ambarwati, et al. (2019) that the methanol and the ethyl acetate extract from $G$. latissima stem bark potentially as antibacterial and the methanol extract also potentially as antioxidant [11][12]. Five out of ten fractions of methanol extract have inhibitory values above $50 \%$ against DPPH radicals. The highest inhibitory fraction value (93.39\%) was the polar fraction.

The limitations of information and research related to $G$. latissima Miq. provide broader exploration opportunities for these plants. In addition, human needs for antioxidants and antidiabetes are still high. Therefore, the main objective of this study is to obtain complete information related to antioxidant and antidiabetic activitiy from the fractions of $G$. latissima Miq. stem bark ethyl acetate extract. The fractions of ethyl acetate extract are expected to have antioxidant activity equal to or higher than the methanol extract. The factions are also expected to be active as an antidiabetic. The benefit of this research is to provide new scientific information about $G$. latissima Miq. stem bark and contributes to the completeness of the bioactivity data of the species G. latissima and genus Garcinia so that it can be preserved for reforestation and as a source of active ingredients for the drug. 


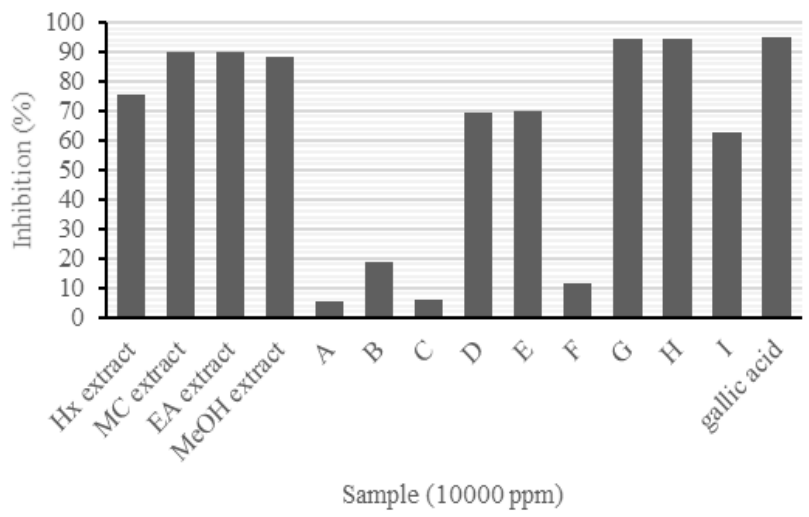

Figure 1. Extracts and fractions inhibition activity against DPPH

\section{METHOD}

\section{A. General Experiment Procedures}

The extract was evaporated using rotary evaporator (Buchi R-210, Swiss). Vacuum liquid chromatography (VLC) were carried out on silica gel $60 \mathrm{G}$ (Merck). Thin layer chromatography (TLC) analysis was used with precoated silica gel $60 \mathrm{~F}_{254}$ (Merck). Absorbance was measured using ultraviolet-visible (UV-VIS) spectrophotometer (Genesys 10S Thermofisher, USA) and microplate reader (Biotek Elx800 UV). All materials are weighed with digital balance (Fujitsu FS-AR210, Japan).

\section{B. Plant Material}

The stem bark of G.latissima Miq. were collected from North Halmahera, Maluku Islands, Indonesia. The plant was identified by Mr. Sudarsono and Mr. Ridwan from Science Center LIPI Bogor, Indonesia. The specimen voucher (No. IV.C.338) was deposited at the Bogor Botanical Garden, Indonesia.

\section{Extraction and Fractination}

The dried $G$. latissima Miq. stem barks $(2.0 \mathrm{~kg})$ were grinded into powder and extracted by maceration at room temperature using ethyl acetate ( $5 \mathrm{~L}$ x $24 \mathrm{hrs}$ ) for three successive days. The filtrate was evaporated to obtain concentrated extract $(240.0 \mathrm{~g})$. The fractination of ethyl acetate extract $(90.0 \mathrm{~g})$ was performed by VLC on silica gel using n-hexane $100 \%$ to obtained fraction $\mathbf{A}$, further fractinations using $n$-hexane:dichlorometane $(9: 1 ; 8: 2 ; 7: 3$; $1: 1 ; 1: 9, v / v)$ to obtained fraction $\mathbf{B}-\mathbf{E}, \mathrm{n}$-hexane:ethyl acetate (1:0 to $0: 1, v / v)$ to obtained fraction $\mathbf{F}-\mathbf{H}$, and methanol 100 $\%$ to obtained fraction $\mathbf{I}$.

\section{Antioxidant Assay against DPPH}

The antioxidant activity was determined using DPPH (2,2diphenyl-1-picrylhydrazil) as a free radical and gallic acid as positive control. The assay was carried out in the dark place because DPPH easily decomposes if exposed to light so that it can cause a decrease in absorbance. Respective fractions $(10.0 \mathrm{mg})$ were dissolved in methanol $(1.0 \mathrm{~mL})$ to obtain stock solution $10000 \mathrm{ppm}$. The fraction stock solution (33.3 $\mu \mathrm{L}$ ) was added in $1.0 \mathrm{~mL}$ DPPH solution $6 \times 10^{-5} \mathrm{M}$. The mixed solutions (triplo) were incubated 20 minutes at room temperature. The absorbance was measured at wavelenght
Table 1.

Antioxidant Activity of Extracts and Fractions Against DPPH

\begin{tabular}{lrr}
\hline \multicolumn{1}{c}{ Sample } & Inhibition $(\%) \pm \mathrm{SD}^{\mathrm{a}}$ & $\mathrm{IC}_{50}(\mu \mathrm{g} / \mathrm{mL})$ \\
\hline Hx extract & $75.28 \pm 0.07$ & 58.88 \\
MC extract & $89.70 \pm 0.01$ & 32.36 \\
EA extract & $90.06 \pm 0.01$ & 17.38 \\
MeOH extract & $88.43 \pm 0.01$ & 8.13 \\
A & $5.37 \pm 0.04$ & $>319.46$ \\
B & $18.72 \pm 0.02$ & $>319.46$ \\
C & $6.04 \pm 0.02$ & $>319.46$ \\
D & $69.49 \pm 0.01$ & $>159.73$ \\
E & $69.90 \pm 0.001$ & $>159.73$ \\
F & $11.49 \pm 0.08$ & $>319.46$ \\
G & $94.36 \pm 0.01$ & 24.55 \\
H & $94.61 \pm 0.02$ & 0.03 \\
I & $62.75 \pm 0.06$ & 0.06 \\
gallic acid & $\mathbf{9 4 . 7 4} \pm \mathbf{0 . 0 0 1}$ & $\mathbf{0 . 0 1}$ \\
\hline \hline
\end{tabular}

$517 \mathrm{~nm}$ [13]. The percentage of DPPH inhibition was obtained according to the formula:

$\%$ inhibition $=\frac{\text { Absorbance of blank-Absorbance of sample }}{\text { Absorbance of blank }} \times 100 \%$ (1)

The respective concentration of fractions $(33.3 \mu \mathrm{L})$ were added in $1.0 \mathrm{~mL}$ DPPH solution $6 \times 10^{-5} \mathrm{M}$. The mixed solutions were incubated 20 minutes at room temperature. Then the absorbance was measured at wavelenght $517 \mathrm{~nm}$ to calculated a percentage of inhibition. The inhibition of $50 \%$ concentration $\left(\mathrm{IC}_{50}\right)$ was tested to the active fraction. The stock solution of the active fraction was diluted to obtain $5000 ; 2500 ; 1250 ; 625$; and $312.5 \mathrm{ppm}$. The value of $\mathrm{IC}_{50}$ was obtained from the value of $\mathrm{x}(\mu \mathrm{g} / \mathrm{mL})$ in linear equation after subtituting $y=50 \%$. Linear equation was formed by using the respective concentration $(\log \mathrm{C})$ as $\mathrm{x}$ and the percentage of inhibition as $\mathrm{y}$.

\section{E. Antidiabetic Assay}

The antidiabetic activity was determined using baker's yeast method and in vitro rat intestinal (sucrose) method and acarbose as positive control which is still actively used as an antidiabetic drug [14]. Sample preparation: A $10000 \mathrm{ppm}$ stock solution was prepared by dissolving $10 \mathrm{mg}$ of the fractions into $1.0 \mathrm{~mL}$ DMSO (dimethyl sulfoxide). The sample concentration was reduced by adding $500 \mu \mathrm{L}$ DMSO to $500 \mu \mathrm{L}$ of stock solution to obtain $5000 \mathrm{ppm}$ solutions which is used for the inhibition assay.

Reagent preparation: Phosphate buffer solution was prepared by dissolving $2.84 \mathrm{~g} \mathrm{Na}_{2} \mathrm{HPO}_{4}$ in $100.0 \mathrm{~mL}$ aqua $\mathrm{DM}$ (a) and dissolving $2.72 \mathrm{~g} \mathrm{KH}_{2} \mathrm{PO}_{4}$ in $100.0 \mathrm{~mL}$ aqua $\mathrm{DM}$ (b). Solutions (a) and (b) are mixed and measured to $\mathrm{pH} 6.9$ with the addition of $\mathrm{NaOH}$ or $\mathrm{HCl} . \mathrm{Na}_{2} \mathrm{CO}_{3} \quad 1.0 \mathrm{mM}$ solution was prepared by dissolving $10.0 \mathrm{~g} \mathrm{Na}_{2} \mathrm{CO}_{3}$ in $100.0 \mathrm{~mL}$ aquades. PNPG ( $p$-nitrophenyl- $\alpha$-D-glucopyranoside) 1.0 $\mathrm{mM}$ substrate is prepared by dissolving $30.0 \mathrm{mg}$ PNPG in $100.0 \mathrm{~mL}$ phosphate buffer solution.

Enzyme preparation: Yeast enzyme solution is prepared by dissolving $1.4 \mathrm{mg}$ of yeast in $20.0 \mathrm{~mL}$ phosphate buffer solution. Rat intestinal enzyme solution is prepared by 
The $6^{\text {th }}$ International Seminar on Science and Technology (ISST) 2020

July $25^{\text {th }}$ 2020, Institut Teknologi Sepuluh Nopember, Surabaya, Indonesia

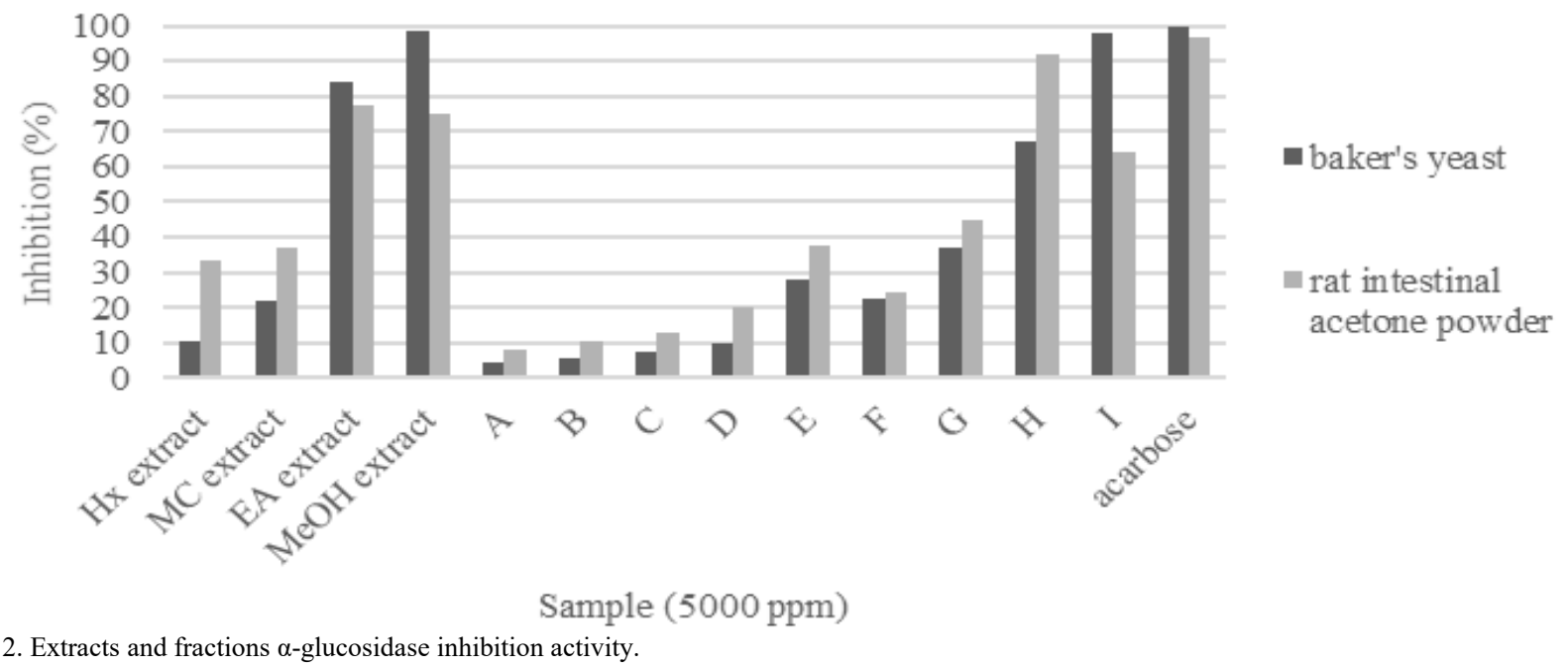

Figure 2. Extracts and fractions $\alpha$-glucosidase inhibition activity.

Table 2.

Antidiabetict Activity of Extracts and Fractions

\begin{tabular}{|c|c|c|c|c|}
\hline \multirow{2}{*}{ Sample } & \multicolumn{2}{|c|}{ Baker's yeast $\alpha$-glucosidase } & \multicolumn{2}{|c|}{ Rat intestinal acetone powder $\alpha$-glucosidase } \\
\hline & Inhibition $(\%) \pm \mathrm{SD}^{\mathrm{a}}$ & $\mathrm{IC}_{50}(\mu \mathrm{g} / \mathrm{mL})$ & Inhibition $(\%) \pm \mathrm{SD}^{\mathrm{a}}$ & $\mathrm{IC}_{50}(\mu \mathrm{g} / \mathrm{mL})$ \\
\hline Hx extract & $10.43 \pm 0.28$ & $>200.0$ & $33.59 \pm 0.02$ & $>312.5$ \\
\hline $\mathrm{MC}$ extract & $22.12 \pm 0.57$ & $>200.0$ & $36.77 \pm 0.02$ & $>312.5$ \\
\hline EA extract & $83.75 \pm 0.21$ & 165.96 & $77.16 \pm 0.09$ & 109.65 \\
\hline $\mathrm{MeOH}$ extract & $98.36 \pm 0.01$ & 23.44 & $75.04 \pm 0.03$ & 123.03 \\
\hline A & $4.15 \pm 0.61$ & $>200.0$ & $8.33 \pm 0.04$ & $>312.5$ \\
\hline B & $5.32 \pm 0.09$ & $>200.0$ & $10.54 \pm 0.04$ & $>312.5$ \\
\hline $\mathrm{C}$ & $7.41 \pm 0.61$ & $>200.0$ & $12.65 \pm 0.07$ & $>312.5$ \\
\hline $\mathrm{D}$ & $10.03 \pm 0.19$ & $>200.0$ & $20.20 \pm 0.06$ & $>312.5$ \\
\hline $\mathrm{E}$ & $28.03 \pm 0.16$ & $>200.0$ & $37.64 \pm 0.03$ & $>312.5$ \\
\hline $\mathrm{F}$ & $22.61 \pm 0.14$ & $>200.0$ & $24.58 \pm 0.01$ & $>312.5$ \\
\hline G & $36.78 \pm 0.12$ & $>200.0$ & $44.92 \pm 0.06$ & $>312.5$ \\
\hline $\mathrm{H}$ & $67.11 \pm 0.36$ & 102.33 & $92.17 \pm 0.02$ & 43.65 \\
\hline I & $97.88 \pm 0.07$ & 29.51 & $64.13 \pm 0.01$ & 75.86 \\
\hline acarbose & $99.44 \pm 0.001$ & 3.31 & $96.76 \pm 0.003$ & 2.95 \\
\hline
\end{tabular}

dissolving $1.0 \mathrm{~g}$ of rat intestinal acetone powder in $30.0 \mathrm{~mL}$ of normal saline. The mixture is stirred with a centrifuge at $3000 \mathrm{rpm}$ for 30 minutes. Then the supernatant is separated from the mixture and used as an enzyme in the assay. Sucrose substrate $100.0 \mathrm{mM}$ is prepared by dissolving $1.72 \mathrm{~g}$ sucrose in $50.0 \mathrm{~mL}$ phosphate buffer solution.

\section{1) Inhibitory Activity Assay for Baker's Yeast $\alpha$ - Glucosidase}

A phosphate buffer solution $50.0 \mu \mathrm{L}$ was put into all the wells of the microwell-plate. Then DMSO $10.0 \mu \mathrm{L}$ was added in wells (1) and (2). While the sample $10.0 \mu \mathrm{L}$ were added in wells (3) and (4). Then $40.0 \mu \mathrm{L}$ yeast enzyme solution was added in wells (2) and (4). Furthermore, the mixture was incubated at $37^{\circ} \mathrm{C}$ for 10 minutes. Then $50.0 \mu \mathrm{L}$ PNPG was added to all the wells. Subsequently, the mixture was incubated again at $37^{\circ} \mathrm{C}$ for 20 minutes. Then the reaction was stopped by adding $100 \mu \mathrm{L} \mathrm{Na}_{2} \mathrm{CO}_{3}$ to all wells and $40.0 \mu \mathrm{L}$ enzymes in wells (1) and (3). The absorbance was measured at a wavelength of $405 \mathrm{~nm}$.

The percentage of inhibition was calculated by equation (1) where A blank = A enzyme reaction (2) - A enzyme reaction blank (1). Meanwhile, A sample = A sample reaction (4) - A sample reaction blank (3). The inhibition of $50 \%$ concentration $\left(\mathrm{IC}_{50}\right)$ was tested to the active fraction. This measurement was carried out on a $2500 ; 1250 ; 625 ; 312.5$; and $156.25 \mathrm{ppm}$.

2) Inhibitory Activity Assay for Rat Intestinal Sucrose

A total of $10.0 \mu \mathrm{L}$ of DMSO was put into wells (1) and (2), while $10.0 \mu \mathrm{L}$ of sample was put into wells (3) and (4). Subsequently, $50.0 \mu \mathrm{L}$ of phosphate buffer was added to wells (1) and (3), while $30.0 \mu \mathrm{L}$ of phosphate buffer was added to wells (2) and (4). Then, sucrose substrate $20.0 \mu \mathrm{L}$ is added to the wells (2) and (4). Next, $80.0 \mu \mathrm{L}$ of glucose kit and $20.0 \mu \mathrm{L}$ of enzyme were added to all the wells of the 
The $6^{\text {th }}$ International Seminar on Science and Technology (ISST) 2020

July $25^{\text {th }} 2020$, Institut Teknologi Sepuluh Nopember, Surabaya, Indonesia

microwell-plate. The mixture was incubated at $37^{\circ} \mathrm{C}$ for 40 minutes. The absorbance was measured at a wavelength of $490 \mathrm{~nm}$.

The percentage of inhibition was calculated by equation (1) where A blank = A enzyme reaction (2) - A enzyme reaction blank (1). Meanwhile, A sample = A sample reaction (4) - A sample reaction blank (3). The inhibition of $50 \%$ concentration (IC50) was tested to the active fraction. This measurement was carried out on a $2500 ; 1250 ; 625 ; 312.5$; and $156.25 \mathrm{ppm}$ sample solution made by diluting the sample solution $5000 \mathrm{ppm}$.

\section{RESULTS AND DISCUSSION}

The ethyl acetate extract from $G$. latissima Miq. stem bark was fractionated by VLC method to yield various polarity fraction from non polar to polar. The number of the yielding fractions are $1.4 \mathrm{~g} \mathrm{~A}, 1.3 \mathrm{~g} \mathrm{~B}, 19.79 \mathrm{~g} \mathrm{C}, 1.6 \mathrm{~g} \mathrm{D}, 1.5 \mathrm{~g} \mathrm{E}$, $303.0 \mathrm{mg}$ F, $410.0 \mathrm{mg} \mathrm{G}, 2.17 \mathrm{~g} \mathrm{H}, 5.2 \mathrm{~g} \mathrm{I}$..

\section{A. Antioxidant Activity}

Antioxidants are compounds to neutralize free radicals that have unpaired free electrons. In the human body, free radicals are formed from oxygen metabolism, such as superoxide anions $\left(\mathrm{O}_{2}{ }^{\circ}\right)$, hydrogen peroxide $\left(\mathrm{H}_{2} \mathrm{O}_{2}\right)$, hudroxyl radicals $\left(\mathrm{OH}^{*}\right)$, singlet oxygen $\left({ }^{1} \mathrm{O}_{2}\right)$. Free radicals are reactive and unstable so that they easily bind to other molecules and form unwanted reactions. The presence of antioxidant compounds can prevent these reactions so there is no damage in the human body. Body damage due to excessive free radicals such as cancer and genetic mutations [15][16]. One of the method to antioxidant assay is using free radicals DPPH.

The antioxidant assay of respective extracts and fractions was performed by DPPH method because it is simple and cheap. Free radical DPPH is purple colored and sensitive to light. The color of DPPH change from purple to yellow when accept hydrogen from antioxidant compound. So that, samples with good inhibitory activity can be seen by changing the color of the solution from purple to yellow and the absorbance was measured at a wavelenght $517 \mathrm{~nm}$ [12][17].

Furthemore, the active fractions were evaluated its IC50. The value of IC50 represents the concentration of fraction that is required for $50 \%$ DPPH inhibition. Based on the value, very potent antioxidant has $\mathrm{IC}_{50}$ below $50.0 \mu \mathrm{g} / \mathrm{mL}$, potent antioxidant has $\mathrm{IC}_{50} 50.0-100.0 \mu \mathrm{g} / \mathrm{mL}$, moderate antioxidant has $\mathrm{IC}_{50} 101.0-150.0 \mu \mathrm{g} / \mathrm{mL}$ and weak antioxidant has $\mathrm{IC}_{50}$ more than $150.0 \mu \mathrm{g} / \mathrm{mL}$.

The assay was carried out on $\mathrm{n}$-hexane $(\mathrm{Hx})$ extract, dichloromethane (MC) extract, ethyl acetate (EA) extract and methanol $(\mathrm{MeOH})$ extract and all fractions that had been obtained from ethyl acetate extract. This was done to determine the relationship between the fraction of ethyl acetate extract on antioxidant activity (inhibition and $\mathrm{IC}_{50}$ on DPPH). Based on the data, it results that all extracts (nhexane, dichloromethane, ethyl acetate, and methanol) from the stem bark of $G$. latissima Miq. were very potent antioxidant. The percentage inhibition of ethyl acetate extract was the highest $(90.06 \%)$ than n-hexane, dichloromethane and methanol extract. However, The $\mathrm{IC}_{50}$ value indicate that methanol extract slightly more active than ethyl acetate extract. It indicating that the antioxidant activity from the $\mathrm{IC}_{50}$ value disproportionately to the percentage inhibition and there is a correlation between the polarity of the fraction and the active inhibition of DPPH so that the fraction activeness increase with increasing polarity. However, $\mathrm{IC}_{50}$ values do not give the same results.

The antioxidant activity from the extracts and fractions can be seen in Figure $\mathbf{1}$ and Table 1. Fraction $\mathbf{H}$ has the highest percentage inhibition $\left(94.61 \%\right.$ ) and the lowest $\mathrm{IC}_{50}$ value $(0.03 \mu \mathrm{g} / \mathrm{mL})$ than other active fractions. According to antioxidant cluster, the extracts and fraction $\mathbf{G}, \mathbf{H}$, and $\mathbf{I}$ can be said as very potent antioxidant. Fraction $\mathbf{H}$ and $\mathbf{I}$ as polar fraction potentially similar to gallic acid. On the other hand, fraction A, B, C, D, E and $\mathbf{F}$ were weak antioxidant. This results provide information about the presence of compounds that has the potential as an antioxidant contained in each extract and active fraction of the ethyl acetate extract $G$. latissima Miq. stem bark. This shows that ethyl acetate extract has quite a lot of antioxidant compounds and its activity are better than methanol extract.

\section{B. Antidiabetic Activity}

Diabetes is a metabolic disorder due to the pancreas damage. The pancreas in the body cannot produce insulin (a hormone regulating blood sugar balance) or cannot use insulin that has been produced effectively. Resulting in hyperglycemia or an increasing glucose concentrations in the body. There are two types of diabetes, namely diabetes type 1 (insulin-dependent or childhood-onset diabetes) due to impaired insulin production in the body and diabetes type 2 (non-insulin-dependent or adult-onset diabetes) due to less effective use of insulin in the body [18][19].

Two types of therapy for diabetics are without drugs (diet and exercise regulation) and drug therapy. Drug therapy for diabetics is exogenous insulin therapy and oral drug therapy. The functions of antidiabetic drugs are to increase insulin secretion in the body, to increase cell sensitivity to insulin, or to inhibit glucose absorption ( $\alpha$-glucosidase enzyme inhibitors) in the body such as acarbose. However, due to the limited types of drugs and the presence of side effects of drugs, there is an opportunity to look for alternative medicines from plants that are expected to have no side effects and to have function as a good inhibitor of $\alpha$ glucosidase and $\alpha$-amylase enzymes. The enzymes $\alpha$ glucosidase and $\alpha$-amylase function to break carbohydrates structure into monosaccharides (glucose, galactose and fructose). Inhibition of the two enzymes causes reduced hydrolysis of carbohydrates resulting the blood glucose levels decreased in the body [20][21].

Antidiabetic assay was carried out on n-hexane extract, dichloromethane extract, ethyl acetate extract and methanol extract as well as all fractions that had been obtained from ethyl acetate extract. The assay was carried out by two methods to find out the differences and or the similarities of the results. The absorbance values from the assay with $\alpha$ glucosidase baker's yeast were measured at a wavelength of $405 \mathrm{~nm}$ because the color of the sample mixture was yellow. 
The $6^{\text {th }}$ International Seminar on Science and Technology (ISST) 2020

July $25^{\text {th }} 2020$, Institut Teknologi Sepuluh Nopember, Surabaya, Indonesia

Whereas the absorbance values from the assay with $\alpha$ glucosidase rat intestinal acetone powder were measured at a wavelength of $490 \mathrm{~nm}$ because the color of the sample mixture was a reddish orange color.

The antidiabetic activity from the extracts and fractions can be seen in Figure 2 and Table 2. Based on the data results, the n-hexane extract and dichloromethane extract did not have good inhibitory activity whereas ethyl acetate extract and methanol extract had good inhibitory activity $(>50 \%)$ against yeast $\alpha$-glucosidase and rat intestinal acetone powder $\alpha$ glucosidase. In addition, the percentage inhibition and $\mathrm{IC}_{50}$ value of the fraction increased from non-polar to polar fractions within the two methods. This shows that there is no significant difference in the two methods. So that it can be informed that the compounds in the extract and the fractions of the G. latissima Miq. stem bark ethyl acetate extract provide the same inhibitory activity against the $\alpha$-glucosidase enzyme from yeast and the $\alpha$-glucosidase enzyme from rat intestinal acetone powder. The ethyl acetate and methanol extracts provide moderate antidiabetic activity compared to positive control. The results shown that the activity of the fraction increases with the increasing polarity.

\section{CONCLUSIONS}

The polar fraction of the G. latissima Miq. stem bark ethyl acetate extract potentially as antioxidant and antidiabetic. The compounds in the polar fraction of atyl acetate extract potentially as an antioxidant and antidiabetic biopharmaceutical material. So that, the active compounds need to be explored and isolated as the drug promotors of antioxidant and antidiabetic.

\section{ACKNOWLEDGMENTS}

Authors wishing to acknowledge to Adi Setyo Purnomo, M. Sc., Ph. D. as the head of the Microorganism Chemistry Laboratory who gave permission for using the microplate reader.

\section{REFERENCES}

[1] E. Bahtera, "Terbesar Kedua di Dunia, Keanekaragaman Hayati Indonesia Baru Tergarap 5\%," 2016. [Online]. Available: http://news.unpad.ac.id/?p=36173. [Accessed: 16-Dec-2017].

[2] B. Santoso, R. S. Utomo, and M. D. Wiyoga, "Analisis Hubungan Senyawa Golongan Flavonoid dari 24 Famili Tanaman terhadap Aktivitas Penangkap Radikalnya," in Prosiding Seminar Nasional Kimia, 2016.

[3] D. Permana et al., "Atrovirisidone B, A New Prenylated Depsidone with Cytotoxic Property from The Roots of Garcinia atroviridis," Zeitschrift fur Naturforsch. - Sect. C J. Biosci., vol. 60, no. 7-8, pp. 523-526, 2005

[4] T. Q. Bui, A. T. Bui, K. T. Nguyen, V. T. Nguyen, B. T. D. Trinh, and L. H. D. Nguyen, "A Depsidone and Six Triterpenoids from The Bark of Garcinia celebica," Tetrahedron Lett., vol. 57, no. 23, pp. 2524-2529, 2016.

[5] M. Y. Ibrahim et al., “ $\alpha$-Mangostin from Garcinia mangostana Linn: An updated review of its pharmacological properties," Arab. J. Chem., vol. 9, no. 3, pp. 317-329, 2016.

[6] Y. Chen, H. Fan, G. Yang, Y. Jiang, F. Zhong, and H. He, "Prenylated Xanthones from the Bark of Garcinia xanthochymus and Their 1,1-Diphenyl-2-picrylhydrazyl (DPPH) Radical Scavenging Activities," Molecules, vol. 15, no. 10, pp. 7438-7449, 2010 .

[7] T. Uji, "Keanekaragaman, Persebaran dan Potensi Jenis-jenis Garcinia di Indonnesia," Penelit. Hayati Berk., vol. 12, pp. 129 135, 2007.

[8] H. M. Sangat, E. A. M. Zuhud, and E. K. Damayanti, Kamus Penyakit dan Tumbuhan Obat Indonesia. Jakarta: Yayasan Obor Indonesia, 2000.

[9] C. Ito, Y. Miyamoto, M. Nakayama, Y. Kawai, K. S. Rao, and H Furukawa, "A Novel Depsidone and Some New Xanthones from Garcinia Species," Chem. Pharm. Bull., vol. 45, no. 9, pp. 14031413, 1997.

[10] R. Purbowati and T. Ersam, "Exploration of Phenolic Compound from The Stem Bark of Garcinia latissima Miq.," J. Sains dan Seni ITS, vol. 8, no. 2, pp. 12-14, 2019.

[11] N. S. S. Ambarwati, B. Elya, A. Malik, and M. Hanafi, "Evaluation of Antimicrobial Activities of Garcinia latissima Miq. Stem Bark Extract," J. Young Pharm., vol. 9, no. 1, pp. 56-59, 2017.

[12] N. S. S. Ambarwati, B. Elya, and Y. Desmiaty, "Anti-elastase Activity of Methanolic and Ethyl Acetate Extract from Garcinia latissima Miq.," in Annual Apllied Science and Engineering Conference, 2019, vol. 1402, no. 055079, pp. 1-5.

[13] W. Brand-Williams, M. E. Cuvelier, and C. Berset, "Use of A Free Radical Method to Evaluate Antioxidant Activity," Leb. Wiss. und Technol., vol. 28, pp. 25-30, 1995.

[14] J. Sichaem, T. Aree, K. Lugsanangarm, and S. Tip-Pyang, "Identification of Highly Potent $\alpha$-glucosidase Inhibitory and Antioxidant Constituents from Zizyphus rugosa Bark: Enzyme Kinetic and Molecular Docking Studies with Active metabolites," Pharm. Biol., vol. 55, no. 1, pp. 1436-1441, 2017.

[15] F. Liu and T. B. Ng, "Antioxidative and Free Radical Scavenging Activities of Selected Medicinal Herbs," Life Sci., vol. 66, pp. 725735,2000

[16] H. F. Maswada, "Assessment of Total Antioxidant Capacity and Antiradical Scavenging Activity of Three Egyptian Wild Plants," J. Med. Sci., vol. 13, no. 7, pp. 546-554, 2013.

[17] S. Chanda and R. Dave, "In vitro models for antioxidant activity evaluation and some medicinal plants possessing antioxidant properties: An overview," African J. Microbiol. Res., vol. 3, no. 13, pp. 981-996, 2009.

[18] Kementrian Kesehatan RI, "Info Datin Diabetes," 2014. [Online] Available: kemkes.go.id/. [Accessed: 06-Jun-2020].

[19] World Health Organization, Global Report on Diabetes. Geneva: WHO Library, 2016.

[20] Departemen Kesehatan RI, Pharmaceutical Care untuk Penyakit Diabetes Mellitus. Jakarta: Dirjen. Bina Kefarmasian dan Alat Kesehatan RI, 2005.

[21] S. Sinulingga, Subandrate, and Safyudin, "Uji Fitokimia dan Potensi Antidiabetes Fraksi Etanol Air Daun Benalu Kersen (Dendrophtoe petandra (L) Miq)," J. Kedokt. dan Kesehat., vol. 16 , no. 1 , pp. 76-83, 2020. 